\title{
sciendo
}

\section{Public debt and inflation dynamics: Empirical evidence from Zimbabwe}

\author{
Talknice Saungweme \\ Department of Economics, University of South Africa, South Africa \\ talknice2009@gmail.com \\ Nicholas M. Odhiambo \\ Department of Economics, University of South Africa, South Africa \\ odhianm@unisa.ac.za; nmbaya99@yahoo.com
}

\begin{abstract}
The study seeks to empirically test the hypothesis that public debt has a significant influence on inflation in Zimbabwe, covering the period 1980-2020. The study was motivated by recent trends in public debt and domestic inflation in Zimbabwe, and the need to guide debt-inflation related policy. These latest trends have started to ring alarming bells, which raises questions on the effectiveness of fiscal and monetary policies in bringing macroeconomic stability in the country. Applying the Autoregressive Distributed Lag (ARDL) bounds testing procedure to cointegration and an error correction mechanism (ECM), expanded by incorporating structural breaks, the study finds evidence in support of positive and significant impact of public debt on inflation dynamics in Zimbabwe, particularly in the long run. Based on the findings, public debt dynamics matter for inflation process in Zimbabwe. That is, fiscal policy can be considered to be an important determinant of the effectiveness of monetary policy in Zimbabwe. Therefore, the government should be mindful of increases in public debt as this was found to be inflationary.
\end{abstract}

Keywords: Autoregressive Distributed Lag (ARDL), inflation, public debt, Zimbabwe.

JEL classification: C32, E31, H63.

DOI: 10.2478/crebss-2021-0007

Received: June 29, 2021

Accepted: September 09, 2021

\section{Introduction}

The interaction between fiscal and monetary policies is a topic that has been widely discussed in economic theory (Mohanty, 2012; Hilbers, 2005). Despite the abundance of literature on the subject, the relationship between these two policies remains complex. Notwithstanding having different policy instruments and being implemented by two different institutions, the influence of the one on the other is strictly intertwined and cannot be easily dichotomised. Fiscal and monetary policies are expected to complement each other to smoothen economic cycles and achieve macroeconomic stability. In reality, however, fiscal imbalances prompt monetisation of public debt (deficit financing), and this has in many instances 
proven to have significant inflationary effects (Mohanty, 2012). That is, unsustainable fiscal imbalances and monetary financing of public debt by the central bank may exert inflationary pressures in the economy leading to other multiple macroeconomic problems.

There are other alternative channels through which rising public debt stocks may directly build up inflationary pressures in the economy. First, are the upward adjustments in tax rates, which may prompt wage-price spiral and therefore inflation and inflationary expectations (Hilbers, 2005; Laidler, Parkin, 1975). Second, are the development of negative perceptions and expectations by economic agents regarding higher taxation levels in the future to facilitate government debt repayments (Sims, 2014). These tax uncertainties adversely impact on investment (private and foreign direct), foreign exchange markets, and financial sector stability (Lawal et al., 2018; Zangari, Caiumi, Hemmelgarn, 2017).

Zimbabwe presents an interesting case worth pursuing for the debt-inflation relationship - given its historical record of public debt overhang and long episodes of hyperinflationary environment. Since independence in 1980, the Zimbabwean government has consistently relied on deficit financing to run the economy (Makochekanwa, 2010). Whereas both public debt and inflation levels were moderate in the 1980s and early 1990s, the twin variables rose exceptionally fast between 1998 and 2009 (Saungweme, Odhiambo, 2018; International Monetary Fund/IMF, 2014). Inflation rose from an average of two-digit figures in 2000 to an estimated peak of 500 billion percent in September 2008 (IMF, 2009). During this period, 1998 to 2008, Zimbabwe was in both severe economic crisis and public debt distress (Government of Zimbabwe/GoZ, 2009a; 2009b; IMF, 2009). Persistent budgetary disproportions were financed largely by: (i) money printing; (ii) extensive borrowing from the banking system; (iii) surrender requirements on export proceeds; (iv) the retention of foreign exchange earnings of the gold and agricultural sectors in excess of mandatory surrender requirements; ( $v$ ) a freeze of most foreign currency deposits; (vi) new foreign borrowing; and (vii) purchases of foreign exchange at the parallel market exchange rates (Mupunga, Le Roux, 2015; IMF, 2009).

Whereas other previous papers have attempted to examine the relationship between public debt and economic growth in Zimbabwe (Saungweme, Odhiambo, 2020; Mupunga, Le Roux, 2014; 2015), none has investigated the possible impact of public debt on inflation. A related paper by Makochekanwa (2010) focused on budget deficits and inflation in Zimbabwe, excluding the impact of public debt dynamics on inflationary process in the country. More so, the paper by Makochekanwa (2010) left out the multicurrency era - 2009-2017. This paper contributes to growing efforts to understand how public debt dynamics influence inflationary process in Zimbabwe. Unlike other previous studies on the subject on Zimbabwe, this paper utilises the ARDL procedure to cointegration and incorporates structural breaks to capture significant structural transformations, such as economic reforms, political changes, and economic shocks, which occurred in the country's economy since 1980. A break is an intermittent shock that has a permanent effect on time series. The ARDL approach has the advantage that it can be applied to variables with mixed order of integration or fractionally integrated (Narayan, Smyth, 2009).

The remainder of the paper is arranged as follows: Section 2 presents trends in inflation and public debt in Zimbabwe, while Section 3 describes the literature on the relation between inflation and public debt. Section 4 explains the data employed, the estimation process followed, and the empirical findings. Finally, the concluding remarks are in Section 5. 


\section{Public debt and inflation dynamics in Zimbabwe}

The evolution of Zimbabwe's public debt dynamics can be traced to 1980 when the country attained political independence. From the 1980s to about 1995, Zimbabwe had unrestricted access to domestic and international capital markets, which contributed to growth in public sector indebtedness (Saungweme, Odhiambo, 2020). However, by the late 1990s, the country was in a serious debt distress, resulting in a massive accumulation of both domestic and foreign debt arrears (Jones, 2011). These arrears led to the drying-up of external development financial grants and cheap offshore finance, further exacerbating the already precarious debt condition in the country (Rehbein, 2012). From 1980 to 1989, Zimbabwe's public debt-to-GDP ratio averaged $29.2 \%$, whereas from 1990 to 1999 , the ratio had increased to $57.2 \%$ (World Bank, 2020).

The hyperinflationary environment that stretched from 2000 to 2008, as well as seignorage revenue, made it possible for the government to redeem a substantial proportion of its domestic debt (Mupunga, Le Roux, 2015). On the whole, the country reached an all-time public debt-to-GDP ratio peak of 106.2\% in 2008 (World Bank, 2020). However, public debt-to-GDP ratio slowed down after 2009 , averaging $73.2 \%$ between 2009 and 2020, reflecting partial improvements in the country's economic performance and debt repayments (IMF, 2020; Mupunga, Le Roux, 2015). Fiscal deficits, however, increased substantially during the period 2016-18, financed largely by the issuance of quasi-currency instruments nominally at par to the US dollar and the continued accumulation of foreign arrears (IMF, 2019a). Foreign public debt arrears totalled US\$5.7 billion at the end of 2017 (IMF, 2019a). Consolidated public sector debt (\% of GDP) between 2016 and 2020 was $68.7 \%, 54.4 \%, 63.2 \%, 57.6 \%$, and $55.9 \%$, respectively (IMF, 2020).

On the inflation front, annual inflation grew from $3.5 \%$ in 1980 to $16.9 \%$ by 1990 (World Bank, 2020). The inflation rate increased exponentially from 2000, reaching triple figures in early 2006 . The country then moved to severe hyperinflation by late 2006, before peaking at 500 billion percent at the end of 2008 (Africa Development Bank, 2011; IMF, 2009). Inflation was fuelled by years of money creation to finance public expenditures and quasi-fiscal spending by the Reserve Bank of Zimbabwe (Africa Development bank, 2011). A prolonged inflationary environment contributed to real output contraction and a substantial reduction in domestic public debt (IMF, 2009).

The hyperinflationary environment ended in February 2009 when the country abandoned its currency in favour of a basket of foreign currency, mostly the US dollar, South African rand, and the Botswana pula. In 2009, the Government of National Unity abandoned monetary injections by the central bank and returned fiscal discipline through strict adherence to a cash budget system (GoZ, 2009a; 2009b).

During the multicurrency era, 2009-2017, inflation remained low and was in the negative territory between 2014 and 2016 (World Bank, 2020). This deflation was a product of the appreciation of the US dollar (Zimbabwe's main trading currency), as well as lower commodity prices (IMF, 2016). However, Zimbabwe remained in debt distress, associated with low levels of international reserves and paltry debt repayments to the IMF (IMF, 2016). Inflation remained in the low single digits through September 2018 but peaked sharply since October 2018 to $622.8 \%$ by September 2020 (IMF, 2020). Figure 1 presents the relationship between public debt (\% of GDP) and annual inflation rate in Zimbabwe over the period 1980-2002, while Table 1 presents the public debt and inflation figures for the period 2009-2020. 


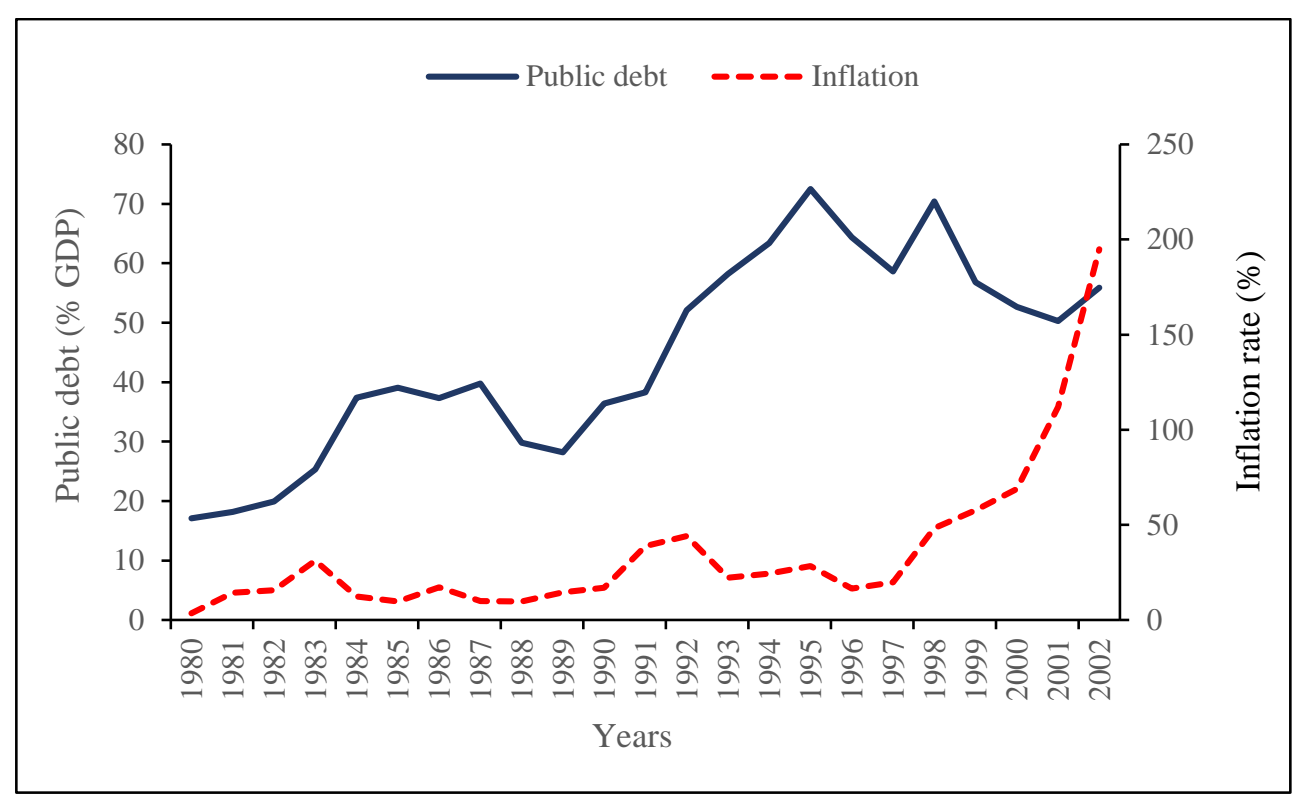

Figure 1 Public debt and inflation in Zimbabwe (1980-2002) Source: Author computation from World Bank data (2020).

Table 1 Public debt and inflation in Zimbabwe (2009-2020)

\begin{tabular}{|c|c|c|}
\hline Year & Public debt (\% GDP) & Inflation rate (\%) \\
\hline 2003 & 66.4 & 598.7 \\
\hline 2004 & 68.7 & 133.3 \\
\hline 2005 & 67.5 & 586.2 \\
\hline 2006 & 78.2 & 1281.1 \\
\hline 2007 & 88.3 & - \\
\hline 2008 & 106.2 & $500\left(10^{9}\right)$ \\
\hline 2009 & 92.3 & 3.0 \\
\hline 2010 & 82.4 & 3.5 \\
\hline 2011 & 76.6 & 3.3 \\
\hline 2012 & 69.8 & 1.6 \\
\hline 2013 & 66.4 & -0.2 \\
\hline 2014 & 76.8 & -2.4 \\
\hline 2015 & 77.5 & -1.6 \\
\hline 2016 & 68.7 & -0.9 \\
\hline 2017 & 54.4 & 3.4 \\
\hline 2018 & 63.2 & 42.1 \\
\hline 2019 & 57.6 & 521.1 \\
\hline 2020 & 55.9 & 622.8 \\
\hline
\end{tabular}

Source: Author computation from World Bank data (2020); IMF (2020).

Figure 1 shows that inflation rates between 1980 and 2002 have been increasing steadily at a time when the public debt-to-GDP ratio was increasing fast. This suggests a positive relationship between public debt and inflation in Zimbabwe. Whereas inflation rates remained below 50\% between 1980 and 1998, an exponential rise in the rate after 1998 is evident in Figure 1, surpassing the public debt-to-GDP ratio in 2001 . The drive to hyperinflation came from (i) the departure from relatively disciplined fiscal policies, which was a detriment to the fiscus; (ii) capital flight due to hostile business environment arising largely from the fast track land reform programme and the indigenous policy - both policy initiatives caused massive disturbances to production in all sectors of the economy and a substantial drop in export volumes and value; (iii) an abrupt currency depreciation hence 
inducing cost-push inflation; and (iv) the liquidity expansion by the central bank embodied in the quasi-fiscal activities (Kairiza, 2012). In 1997, the government paid ZW $\$ 50000$ (approximately USD3 000 at the time) each to about sixty thousand war veterans, in addition to a monthly pension of approximately USD125 per month (Chitiyo, 2000). The payouts inflated the budget deficit at the end of 1997 (Makochekanwa, 2010). According to Amani Trust (1998), the government had envisioned to accommodate the gratuities payment through tax increases in the 1998 budget an initiative that was resisted by the trade unions, forcing the government to opt for monetisation of the transaction - hence the upward trend of inflation evident in Figure 1.

The data presented in Table 1 can be widely bundled into two clusters, 2003-2008 and 2009-2020. In the first phase, 2003-2008, the country's economy was contracting, with both public debt/GDP and inflation rising at unprecedented rates. Towards the end of this era, 2007-2008, Zimbabwe inflation soared, reaching a historic monthly and yearly record of 79.6 billion and 500 billion percent, respectively, in 2008 (IMF, 2009; Hanke, Kwok, 2009). The central bank continued to increase the money supply, mainly because of the quasi-fiscal activities, and with it more inflation (Hanke, Kwok, 2009). Unfortunately, from August 2007, the Reserve Bank of Zimbabwe and Zimbabwe Statistical Agency stopped publishing economic data, particularly on inflation.

However, in the second phase, the country experienced a stable economic recovery after a decade of contraction. As Table 1 shows, both public debt and inflation maintained a structurally downward trend between 2009 and 2013 reflecting the adoption of a multicurrency regime and a return to fiscal discipline through strict adherence to a cash budget system (Goz, 2009a). Three inflation periods can be identified in Table 1: (i) 2009-2013 where inflation was generally stable, averaging $2.3 \%$ per annum; (ii) 2014-2015 where the country was experiencing a deflationary environment, mainly driven by external factors such as the appreciating of the US dollar, falling international oil and food prices; and (iii) 2016-2020 where inflation increased significantly from $42.1 \%$ in December 2018 to an estimated $521.1 \%$ by end 2019 , being caused by the depreciation of the exchange rate, broad money supply growth, and removal of fuel and electricity subsidies (World Bank, 2020; IMF, 2020: 121; Nyarota et al., 2016). Since 2018, domestic financing has increased, and the share of foreign currency debt has decreased marginally (Ministry of Finance and Economic Development, 2021). The recent increase in inflation and a slight decrease in debt/GDP ratio might mean that the rise in inflation is liquidating government domestic debt. In the main, while public debt and inflation rate co-moved during the review period, it remains uncertain if the former influence the latter; and this can be determined empirically.

\section{Public debt and inflation: A review of literature}

There exists in literature divergent theoretical considerations on the determinants of inflation. More so, the independence of central banks in achieving price stability has been an issue of intense debate in previous studies (e.g. Mas et al., 2020; Radovic, Radonjic, Djuraskovic, 2018; Dedu, Stoica, 2012). The first view, the monetarist/classical view, assumes that inflation is fundamentally a monetary phenomenon (Friedman, 1970). According to Friedman (1970), inflation arises when there is a more rapid increase in the quantity of money than output (e.g. Mankiw, 2012; Laidler, Parkin, 1975).

The interaction between price stability and fiscal operations, if public debt is denominated in nominal terms, is further explained by Barro (1989). According to 
Barro (1989), other things being equal, a higher rate of expected inflation (probably suggesting excessive monetary growth) motivates a correspondingly higher growth rate of the nominal public debt. The Ricardian view by Barro presumably reflects that the planned path of the real public debt is invariant with expected inflation - hence budget deficits do not create net wealth (Barro, 1989).

The second view, the Keynesian view, makes a distinction between supply-side factors (that occur in factor markets leading to cost-push inflation) and demand-side factors (that take place in product markets resulting in demand-pull inflation). Keynes' theory of inflation is essentially a demand pull-inflation theory, where inflation is caused by further increases in effective demand after full employment is attained (Keynes, 1936). Keynes (1936) further argues that the interaction between prices and wages, referred to in some circles of literature as the Fiscal Theory of the Price Level (FTPL), is modelled by the expectations of economic agents. When expectations are not fulfilled, adjustments will occur partly on quantities of employment, inventories, demand patterns, and largely on prices, particularly in the long run (Mohr, 2008; Keynes, 1936). Thus, the FTPL assumes that fiscal policy alone can dominantly influence inflation regardless of monetary policy (e.g. Sims, 2014; 2016).

The empirical literature can be grouped into two - studies supporting a positive impact of public debt on inflation and studies supporting a negative impact of public debt on inflation. The positive impact of public debt on inflation is supported in the literature by Aimola and Odhiambo (2021), Romero and Marin (2017), Nguyen (2015), among others. Contrary, the negative impact of public debt on inflation is supported in the literature by Hilscher, Raviv and Reis (2020), Afonso and Jalles (2019), IMF (2019b), and Lopes da Veiga, Ferreira-Lopes and Sequeira (2016).

Aimola and Odhiambo (2021) investigated the impact of public debt on inflation in Ghana using annual data covering the period from 1983 to 2018 . Applying the autoregressive distributed lag bounds testing approach to cointegration and an error correction model, in the presence of a structural break, the authors found evidence consistent with a positive relationship between public debt and inflation in Ghana, both in the short run and long run.

Hilscher, Raviv and Reis (2020) assessed the impact of future inflation on the real value of outstanding public debt in the United States of America. The authors found a negative relationship between public debt and inflation. The relationship was found to be influenced by debt-holder profile, debt maturity profile, and the stochastic properties of future inflation, including its volatility and persistence.

Afonso and Jalles (2019) studied the fiscal consequences of deflation on a panel of 17 economies in the first wave of globalisation using historical data over the period of 1870 to 1914. Using impulse response analyses and panel regressions, the results show that a $1 \%$ fall in the price level is associated with an increase in the public debt ratio of between $0.23 \%$ and $0.33 \%$ points.

The IMF (2019b) assessed the impact of inflation shocks on the public debt-to-GDP ratio in 19 advanced economies using simulation and estimation approaches. The findings from both approaches suggest that a $1 \%$ point shock to inflation rate reduces the public debt-to-GDP ratio by about $0.5-1 \%$ points. The results further suggest that the impact is stronger and more persistent when the public debt maturity is longer. Also, the research outcome implies that modestly higher inflation, even if complemented by some financial repression, could marginally reduce public debt burden in many advanced economies.

Romero and Marin (2017) analysed the relationship between public debt, economic growth, money supply growth, and inflation using a sample of 52 net debtor countries over the period 1961-2015. Employing the VAR panel data 
estimation technique, the authors found that an increase in public debt is inflationary, particularly in countries whose public debt was already high. That is, an increase in the public debt/GDP ratio was strongly associated with high inflation in highly indebted developing countries. Contrary, the findings indicated that the debtinflation relationship was not significant for developed countries.

Lopes da Veiga, Ferreira-Lopes and Sequeira (2016) analysed the implications of public debt on economic growth and inflation in a group of 52 African economies for the period covering 1950 to 2012. The results show that high levels of public debt are associated with reduced rates of economic growth and rising levels of inflation.

Nguyen (2015) examined the impact of public debt on inflation with control variables of money supply, real GDP per capita, private investment, budget revenue, government investment, government current expenditure and trade openness in 15 developing economies of Asia, for the period from 1990 to 2012. The authors utilised the Pooled Mean Group estimation and panel differenced GMM Brundell-Bond regression techniques to test the government debt-inflation nexus. The results show that public debt, economic growth, broad money supply, public investment, and trade openness are significantly inflationary in studied economies of Asia suggesting a positive relationship between the variables.

Kwon, McFarlane and Robinson (2009) investigated the relationship between public debt and inflation using panel data covering the period from 1963 to 2004 for 71 countries - composed of developing and developed countries. Using ordinary least squares estimation and a VAR model, the results indicate that the relationship between public debt and inflation holds strongly and positive in indebted developing countries, weakly in other developing countries, but generally not in developed economies.

Apart from the above-cited studies on public debt-inflation linkage, there is a long strand of empirical literature on the relationship between inflation and public debt. These studies include Cherif and Hasanov (2018), Krause and Moyen (2016), End ef al. (2015), Reinhart and Sbrancia (2015), and Akitoby, Komatsuzaki and Binder (2014), among others. In the main, however, the explored empirical literature in this study provides evidence supporting both positive and negative impact of public debt on inflation. Overall, this literature survey shows that the impact of public debt on inflation varies across studied economies.

\section{Research methodology Data availability and definition of variables}

The study utilises annual time series data for the period 1980-2020. The data for all variables come from World Development Indicators, an electronic database of the World Bank. The variables included in the study comprise inflation, public debt, money supply, interest rate, investment, and real per capita income (a proxy for economic growth). Table 2 outlines the definitions and a priori expectation of each variable.

Table 2 Variable description and a priori expectation

\begin{tabular}{|l|l|c|}
\hline \multicolumn{1}{|c|}{ Variable } & \multicolumn{1}{|c|}{ Variable description } & A priori expectation \\
\hline Inflation & Consumer prices (annual \%) & - \\
\hline Public debt & Total public debt (\% of GDP) & Positive \\
\hline Money supply & Broad money supply (\% of GDP) & Positive \\
\hline Interest rate & Monetary policy rate (annual \%) & Positive \\
\hline Investment & Gross fixed capital formation (\% of GDP) & Negative \\
\hline Real per capita income & $\begin{array}{l}\text { Real GDP / Total population (proxy for } \\
\text { economic growth) }\end{array}$ & Positive \\
\hline
\end{tabular}




\section{Estimation techniques - ARDL bounds testing procedure}

In this study, the ARDL bounds testing approach is applied to examine the long-run cointegration relationship between public debt and inflation (Narayan, Smyth, 2009; Pesaran, Shin, Smith, 2001). Since Zimbabwe has been subjected to various economic shocks likely to have affected its debt policies, the trends of its debt/GDP ratio and inflation hints of structural changes. The estimation model used in this paper, therefore, accounted for structural breaks in the inflation series based on Zivot-Andrews (ZA) unit root test (e.g. Uctum, Thurston, Unctum, 2006). The ZivotAndrews (1992) test is basically a modification of the Phillip-Perron (1988) unit root test (Uctum, Thurston, Unctum, 2006).

The ZA test determines endogenously whether the series are trend-stationary in the presence of a one-time structural break in the series (Uctum, Thurston, Unctum, 2006) (Appendix for the Zivot and Andrews (1992) unit root test functions). The ZA test allows for a single break in the intercept and the trend-slope of the series (Zivot, Andrews, 1992). Testing for stationarity allowing for structural breaks has two main advantages: (i) it prevents the unit root test results from becoming bias towards unit root - which is a common problem in conventional unit root tests; and (ii) it can identify when a possible break occurred (Glynn, Perera, Verma, 2007).

The selection of the breakpoint for the dummy variable in equations $A 1, A 2$ and A3 in Appendix 1 is viewed as an outcome of an estimation procedure that is designed to fit $b_{t}$ to a certain trend-stationary representation (Glynn, Perera, Verma, 2007; Zivot, Andrews, 1992). That is, the ZA test assumes that the alternative hypothesis specifies that $b_{t}$ can be a trend-stationary process with one break in the trend that occurs at an unknown point in time (Zivot, Andrews, 1992). The goal of the ZA test is to find the breaking point that supports this hypothesis the most (Glynn, Perera, Verma, 2007). Thus, the ZA test estimates a regression for every possible break date chronologically and the year of structural changes is determined based on the most significant t-statistics for $\alpha$ (Saatcioglu, Korap, 2008).

To fully specify the model, four control variables were added, namely, money supply, interest rates, investment and real per capita income. Hence, the estimated ARDL model is specified as:

$$
\begin{gathered}
\Delta \pi_{t}=\phi_{0}+\sum_{i=1}^{n} \phi_{1 i} \Delta \pi_{t-i}+\sum_{i=0}^{n} \phi_{2 i} \Delta p d_{t-i}+\sum_{i=0}^{n} \phi_{3 i} \Delta m s_{t-i}+\sum_{i=0}^{n} \phi_{4 i} \Delta i n t_{t-i} \\
+\sum_{i=0}^{n} \phi_{5 i} \Delta i n v_{t-i}+\sum_{i=0}^{n} \phi_{6 i} \Delta y_{t-i}+\phi_{7} \pi_{t-1}+\phi_{8} p d_{t-1}+\phi_{9} m s_{t-1} \\
+\phi_{10} i n t_{t-1}+\phi_{11} i n v_{t-1}+\phi_{12} y_{t-1}+\phi_{13} D U_{09}+\mu_{1 t}
\end{gathered}
$$

where $\pi$ is log of consumer inflation; pd is log of public debt; ms is log of money supply; int is log of interest rate; inv is log of investment; y log of real per capita income; $\phi_{0}$ is a constant; $\phi_{1}-\phi_{6}$ are the short-run coefficients; $\phi_{7}-\phi_{13}$ are the long-run coefficients; $\Delta$ is the difference operator; $\mathrm{n}$ is the maximum lag length; $\mu_{1 \mathrm{t}}$ is the error term; $\mathrm{t}$ is the time period; and DU is the dummy variable.

The bounds F-testing procedure is used in this study to test the existence of the long-run relationship of the variables in the inflation model (equation 1). In the bounds F-testing procedure, the null hypothesis of no cointegration among the variables in equation (1) is tested against the alternative hypothesis that there is a cointegration among the variables under study (Pesaran, Shin, 1999; Pesaran, Shin, Smith, 2001). The computed F-statistic is compared with two sets of critical values reported by Pesaran and Shin (1999) and Pesaran, Shin and Smith (2001) for the three 
given significance levels $-1 \%, 5 \%$ and $10 \%$ (e.g. Odhiambo, 2021a). The first set of critical values assumes that all variables included in the ARDL model are integrated of order zero $[1(0)]$, while the other set assumes that the variables are integrated of order one [I(1)] (e.g. Narayan, Smyth, 2009). When the computed test statistic exceeds the upper critical bounds value, [I(1)], then the null hypothesis is rejected (e.g. Odhiambo, 2021a; Narayan, Smyth, 2009). When the computed F-statistic is lower than the lower bounds value, [l(0)], then the null hypothesis of no cointegration cannot be rejected (e.g. Narayan, Smyth, 2009). However, when the F-statistic falls into the bounds, the cointegration test becomes inconclusive (e.g. Odhiambo, 2021b; Narayan, Smyth, 2009).

The ECM model based on Equation 1 is given as Equation 2:

$$
\begin{aligned}
\Delta \pi_{t}=\phi_{0}+\sum_{i=1}^{n} \phi_{1 i} \Delta \pi_{t-i}+\sum_{i=0}^{n} \phi_{2 i} \Delta p d_{t-i}+\sum_{i=0}^{n} \phi_{3 i} \Delta m s_{t-i}+\sum_{i=0}^{n} \phi_{4 i} \Delta i n t_{t-i} \\
+\sum_{i=0}^{n} \phi_{5 i} \Delta i n v_{t-i}+\sum_{i=0}^{n} \phi_{6 i} \Delta y_{t-i}+\sum_{i=0}^{n} \delta_{1} \Delta D U_{09 ; t-i}+\psi_{1} E C M_{t-1} \mu_{2 t}
\end{aligned}
$$

where $\delta_{1}$ is the short-run coefficient of the dummy variable; $\psi_{1}$ is the coefficient of $\mathrm{ECM}_{\mathrm{t}-1} ; \mathrm{ECM}_{\mathrm{t}-1}$ is the error-correction term lagged by one period; and all variables remain as defined in Equation 1.

The error-correction term lagged by one period, $E C M_{t-1}$, is obtained from the long-run equilibrium relationship (the estimated cointegrated equation). The coefficient of $E C M_{t-1}, \psi_{1}$, signifies the speed of adjustment at which inflation reverts to its long-run equilibrium position following a shock in the economy (Madito, Odhiambo, 2018). For stability and convergence to long-run equilibrium to be achieved after a shock in the economy, $\psi_{1}$ must be within the $(0,-1)$ interval.

\section{Empirical results and analysis Stationarity test results}

As with other time-series data techniques, this study performed stationarity tests of variables using the Dickey-Fuller Generalised Least Square (DF-GLS) and the PhillipsPerron (PP) unit root tests proposed by Newey and West (1987) and Elliot, Rothenberg and Stock (1996), respectively. The lag lengths in DF-GLS and PP were spontaneously selected by Schwarz Information Criterion (SIC) and Newey-West bandwidth test truncation lag techniques, respectively (Newey, West, 1987). The results of the stationarity tests are presented in Tables 3 and 4.

The results reported in Tables 3 and 4 show that investment is integrated of order zero, [l(0)], whereas inflation, public debt, money supply, interest rate and economic growth are integrated of order one, [I(1)]. The confirmation that the order of integration of the variables used in the study is at most one certifies the applicability of the ARDL bounds approach.

The conventional unit root tests performed above are usually weak in the face of structural breaks. Therefore, prior to the application of the bounds F-test for cointegration, the study implemented the ZA structural break unit root tests, allowing for one endogenously determined structural break. The null hypothesis is that inflation has a unit root with a structural break in both the intercept and trend. The summary of results of the ZA test are reported in Table 5. 
Table 3 Stationarity test of all variables: DF-GLS test

\begin{tabular}{|c|c|c|}
\hline Variable & $\begin{array}{c}\text { Stationarity of all } \\
\text { variables in levels }\end{array}$ & $\begin{array}{c}\text { Stationarity of all variables in first } \\
\text { difference }\end{array}$ \\
\hline$\pi$ & -2.085 & $-5.970^{* * *}$ \\
\hline $\mathrm{pd}$ & -1.378 & $-5.300^{* * *}$ \\
\hline $\mathrm{ms}$ & -2.186 & $-5.671^{* * *}$ \\
\hline int & -2.506 & $-5.819^{* * *}$ \\
\hline inv & $-3.399^{* *}$ & - \\
\hline $\mathrm{y}$ & -1.406 & $-4.981^{* * *}$ \\
\hline
\end{tabular}

Notes: ${ }^{* * *}$ and ${ }^{* *}$ denote stationarity at $1 \%$, and $5 \%$ significance levels, respectively.

Table 4 Stationarity test of all variables: PP test

\begin{tabular}{|c|c|c|}
\hline Variable & $\begin{array}{c}\text { Stationarity of all } \\
\text { variables in levels }\end{array}$ & $\begin{array}{c}\text { Stationarity of all variables in first } \\
\text { difference }\end{array}$ \\
\hline$\Pi$ & -2.217 & $-6.073^{* * *}$ \\
\hline $\mathrm{pd}$ & -1.659 & $-5.192^{* * *}$ \\
\hline $\mathrm{ms}$ & -2.066 & $-5.490^{* * *}$ \\
\hline int & -2.970 & $-6.741^{* * *}$ \\
\hline inv & $3.435^{* *}$ & - \\
\hline $\mathrm{Y}$ & -1.501 & $-5.213^{* * *}$ \\
\hline
\end{tabular}

Notes: ${ }^{* * *}$ and ${ }^{* *}$ denote stationarity at $1 \%$, and $5 \%$ significance levels, respectively.

Table 5 Stationarity test of all variables: ZA test

\begin{tabular}{|c|c|c|c|}
\hline Variable & $\begin{array}{c}\text { Stationarity of all } \\
\text { variables in levels }\end{array}$ & $\begin{array}{c}\text { Stationarity of all variables in first } \\
\text { difference }\end{array}$ & Break year \\
\hline$\pi$ & -4.917 & $-6.434^{* * *}$ & 2009 \\
\hline $\mathrm{pd}$ & -2.624 & $-5.486^{* *}$ & 2007 \\
\hline $\mathrm{ms}$ & -3.518 & $-6.039^{* * *}$ & 2009 \\
\hline int & -4.902 & $-6.172^{* * *}$ & 2009 \\
\hline inv & $-5.578^{* *}$ & - & 1999 \\
\hline $\mathrm{y}$ & $-5962^{* *}$ & - & 2009 \\
\hline
\end{tabular}

Notes: ${ }^{* * *}$ and ${ }^{* *}$ denote stationarity at $1 \%$, and $5 \%$ significance levels, respectively.

The results of the ZA test presented in Table 5 confirm previous findings, reported in Tables 3 and 4, that none of the study variables is I(2) and further show that the structural change in inflation took place in 2009. The year 2009 coincides with the political change that occurred in Zimbabwe when the country formed the Government of National Unity. The new government instituted substantial economic reforms such as the implementation of a multicurrency management and strict adherence to a cash budget system (IMF, 2014; GoZ, 2009a; 2009b). These political, economic and monetary transformations radically reduced inflation rate, focusing largely on the use of market-based fiscal and monetary policies (World Bank, 2020; IMF, 2014).

\section{ARDL bounds test for cointegration results}

The Akaike Information Criterion test was applied in order to determine the optimal lag length of each variable. The results of the ARDL bounds for cointegration are reported in Table 6.

The results of the ARDL bounds cointegration test presented in Table 6 show that the calculated F-statistic is higher than the upper bound critical value at the $1 \%$ level. This implies that there is a unique cointegration vector between inflation, public debt, money supply, interest rate, investment, real per capita income, and the dummy variable. 
Table 6 ARDL-bounds test for cointegration results

\begin{tabular}{|c|c|c|c|c|c|c|c|}
\hline $\begin{array}{c}\text { Dependent } \\
\text { variable }\end{array}$ & \multicolumn{4}{|c|}{ Function } & F-statistic & \multicolumn{2}{|c|}{$\begin{array}{c}\text { Cointegration } \\
\text { status }\end{array}$} \\
\hline Inflation (ח) & \multicolumn{3}{|c|}{$F(\pi \mid$ pd, ms, int, inv, y, DUo9) } & & $8.716^{* * *}$ & \multicolumn{2}{|c|}{ Cointegrated } \\
\hline \multicolumn{8}{|c|}{ Asymptotic critical values (unrestricted constant and no trend) } \\
\hline \multirow{3}{*}{\multicolumn{2}{|c|}{$\begin{array}{l}\text { Pesaran, Shin and Smith } \\
\text { (2001) critical values } \\
\text { [Case 3] }\end{array}$}} & \multicolumn{2}{|c|}{$1 \%$} & \multicolumn{2}{|c|}{$5 \%$} & \multicolumn{2}{|c|}{$10 \%$} \\
\hline & & $1(0)$ & $1(1)$ & $\mathrm{I}(0)$ & $1(1)$ & $1(0)$ & $\mathrm{I}(1)$ \\
\hline & & 2.54 & 3.86 & 2.06 & 3.24 & 1.83 & 2.94 \\
\hline
\end{tabular}

Notes: ${ }^{* * *}$ signifies statistical significance at $1 \%$.

\section{Long-run and short-run estimation results}

The estimated long-run and short-run coefficients for Equation (1) are reported in Table 7, Panels A and B, respectively.

Table 7 Long-run and short-run coefficients

\begin{tabular}{|c|c|c|c|}
\hline \multicolumn{4}{|c|}{ Panel A: Estimated long-run coefficients (elasticities): Regressand: log of consumer inflation $\left(\boldsymbol{\pi}_{t}\right)$} \\
\hline Regressors & Coefficient & t-ratio & p-value \\
\hline constant & $-15.381^{* *}$ & -2.421 & 0.028 \\
\hline $\mathrm{pd}$ & $1.104^{* *}$ & 2.960 & 0.019 \\
\hline $\mathrm{ms}$ & $1.469 * * *$ & 3.986 & 0.001 \\
\hline int & $1.204^{* * *}$ & 3.121 & 0.004 \\
\hline inv & 0.059 & 0.179 & 0.860 \\
\hline y & 0.973 & 0.380 & 0.707 \\
\hline $\mathrm{DU}_{09}$ & 0.141 & 0.272 & 0.788 \\
\hline \multicolumn{4}{|c|}{ Panel B: Estimated short-run coefficients (elasticities): Regressand: log of consumer inflation $\left(\Delta \boldsymbol{\pi}_{\mathbf{t}}\right)$} \\
\hline Regressors & Coefficient & t-ratio & p-value \\
\hline$\Delta \pi(1)$ & $0.140^{* *}$ & 2.433 & 0.024 \\
\hline$\Delta \mathrm{pd}$ & $0.877^{*}$ & 1.961 & 0.069 \\
\hline$\Delta \mathrm{ms}$ & $1.542^{* * *}$ & 6.134 & 0.000 \\
\hline$\Delta$ int & $1.295^{* * *}$ & 3.848 & 0.001 \\
\hline$\Delta$ inv & 0.111 & 0.358 & 0.723 \\
\hline$\Delta \operatorname{inv}(1)$ & $-0.567^{*}$ & -1.819 & 0.080 \\
\hline$\Delta y$ & 1.263 & 0.967 & 0.342 \\
\hline$\Delta \mathrm{DU}_{09}$ & -1.739 & ,-1.344 & 0.184 \\
\hline$E C M_{t-1}$ & $-0.590 * * *$ & -3.183 & 0.001 \\
\hline
\end{tabular}

As Table 7 [Panel A] shows, the results indicate that in the long-run, public debt, money supply and interest rates are inflationary and statistically significant at the $5 \%$, $1 \%$ and $1 \%$ significance levels, respectively. This outcome implies that public debt positively influences inflationary processes in Zimbabwe in the long run - meaning that public debt dynamics may be pushing up the general price level. In line with the findings, there is room to suggest that the Zimbabwean government is using monetary means to finance part of its debt (e.g. IMF, 2019a; 2009). The result is in line with the study expectations and is consistent with the findings in Romero and Marin (2017) and Nguyen (2015). Although investment and real per capita income have the expected positive sign, they were found to be statistically insignificant in the long run.

The short-run results presented in Panel B of Table 7 reveal that the relationship between public debt and inflation dynamics is positive and statistically significant in the short run. This result is not unique to this study as it is consistent with previous studies such as Kwon, McFarlane and Robinson (2009). Further, inflation in the previous year, money supply and interest rate in the current year were found to positively affect inflation in a significant way. In view of both long-run and short-run 
results, there is evidence that public debt, money supply and interest rate have a statistically significant and positive impact on inflation process in Zimbabwe. These findings are supported in empirical literature by studies such as Nguyen (2015) and Mankiw (2012), and theoretically by Friedman (1970). Conversely, investment in the current period, real per capita income and the dummy variable are statistically insignificant in the short run, implying that they have no impact on inflation.

Furthermore, the short-run results show that investment lagged by one period has a statistically significant and negative impact on inflation, which is consistent with prior expectations. In literature, uncertainty linked with a high and explosive unanticipated inflation negatively affects the rate of return of capital and investment (e.g. Andrés and Hernando, 1997). Similarly, low levels of investment fuel demand pull-inflation (e.g. Mohr, 2008). Lastly, as regards the speed of adjustment, the coefficient of the error-correction term lagged by one period $\left(E C M_{t-1}\right)$ has the expected negative sign and within the $(0,-1)$ interval and statistically significant at the $1 \%$ significance level. This implies that in the event of a shock to the Zimbabwean economy, inflation adjusts to equilibrium at a rate of $59 \%$ per annum.

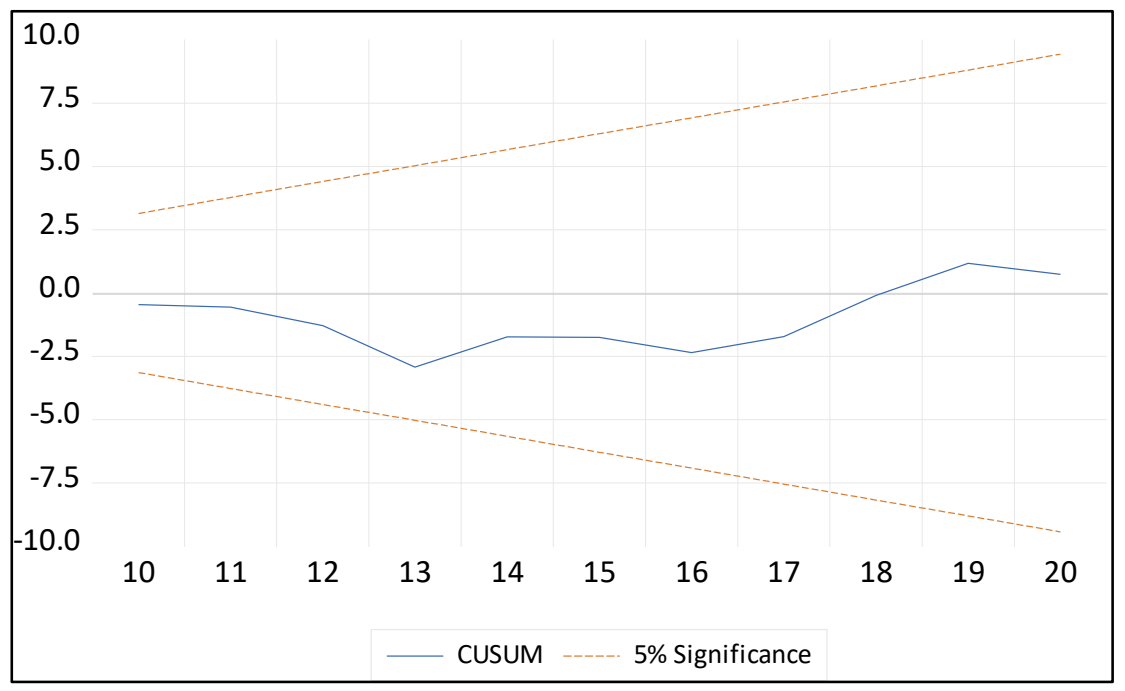

Figure 2 CUSUM plot

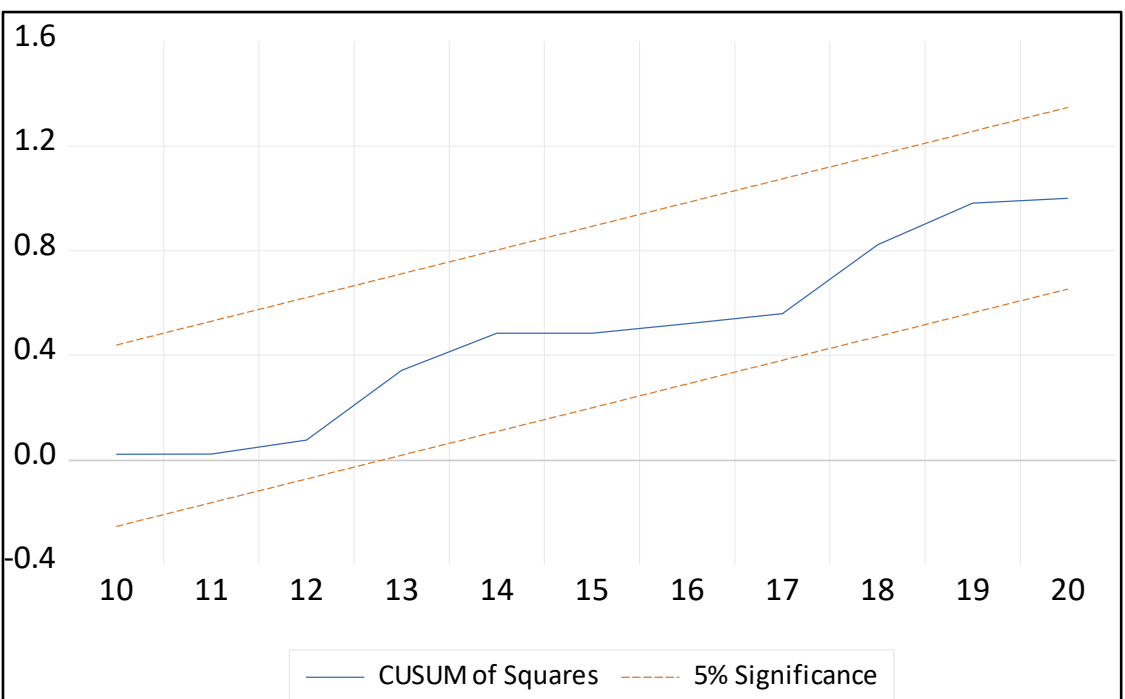

Figure 3 CUSUMSQ plot 
The performed model stability tests show that the plots of the cumulative sum of recursive residuals (CUSUM) and cumulative sum of squares of recursive residuals (CUSUMQ), presented in Figures 2 and 3, are within the 5\% bounds. This implies that the model is stable, and the estimated results are consistently reliable.

\section{Concluding remarks and policy implications}

In this paper, the authors analysed the impact of public debt on inflation process in Zimbabwe, covering the period 1980-2020. Zimbabwe is among the developing countries in the world that are battling with high levels of inflation and are in severe public debt distress (IMF, 2020). The study employed the autoregressive distributed lag bounds testing approach to cointegration and an error correction model. The study incorporated structural breaks following the Zivot and Andrews (1992) unit root test. The four control variables included in the model were money supply, interest rate, investment and real per capita income. The ARDL bounds test results show evidence of the existence of a long-run and short-run equilibrium relationship between public debt and inflation. The study finds evidence in support of a statistically significant and positive impact of public debt on inflation dynamics in Zimbabwe, irrespective of the time frame considered. The results further show that money supply and interest rate positively drive inflation process in Zimbabwe, irrespective of whether the regression analysis is carried out in the short or long run. Based on the findings, therefore, public debt dynamics matter for inflation process in Zimbabwe. Therefore, the government should be mindful of increases in public debt as this was found to be inflationary.

Consequently, the study recommends that the government clears outstanding foreign public debt arrears and prioritise strict adherence to proper public financial management practices. There is also a need to continue growing the domestic revenue base and increase revenue mobilisation efforts and efficiency. This helps to reduce macroeconomic imbalances that lead to public debt and hence inflationary pressures of a fiscal origin.

In conclusion, the study noted that since 2018, domestic financing has increased, and the share of foreign currency debt has decreased marginally. This fiscal dominance in the economy may have a significant implication for monetary policy in the future. Therefore, it may be prudent to revisit the debt-inflation nexus in Zimbabwe in the foreseeable distant future to capture these new developments. Finally, future researches on the subject should consider testing the possibility of the nonlinear impact of public debt on inflation in Zimbabwe.

This paper acknowledges a growing body of recent empirical literature that suggest that the relationship between inflation and public debt is nonlinear and that there, therefore, exists a certain threshold beyond which inflation increases public debt and below which the relationship is insignificant. The paper also left out causality analyses between the two variables of interest - inflation and public debt. This paper, therefore, recommends that future studies on the subject perform a precise estimation of the threshold level and the direction of causality between inflation and public debt in the study country.

\section{References}

1. Afonso, A., Jalles, J. T. (2019). The fiscal consequences of deflation: Evidence from the golden age of globalisation. Quarterly Review of Economics and Finance, Vol. 74, No. 1, pp. 129-147. 
2. Africa Development Bank. (2011). From Stagnation to economic recovery. Available at https://www.afdb.org/fileadmin/uploads/afdb/Documents/GenericDocuments/3.\%20Zim babwe\%20Report_Chapter\%201.pdf [14 February 2021].

3. Aimola, A. U., Odhiambo, N. M. (2021). Public debt and inflation: empirical evidence from Ghana. Development Studies Research, Vol. 8, No. 1, pp. 1-13.

4. Akitoby, B., Komatsuzaki, T., Binder, A. (2014). Inflation and public debt reversals in the G7 countries. IMF Working Paper WP/14/96. Available at https://www.imf.org/external/pubs/ft/wp/2014/wp 1496.pdf [13 February 2021].

5. Amani Trust (1998). A consolidated report on the food riots: 19-23 January 1998. Zimbabwe Human Rights NGO Forum. Available at http://www.hrforumzim.com/members_reports/foodriots98/food9801.htm [07 March 2021].

6. Andrés, J., Hernando, I. (1997). Inflation and economic growth: Some evidence for the OECD countries. Available at https://www.bis.org/publ/confp04p.pdf [24 February 2021].

7. Barro, R. J. (1989). The Ricardian approach to budget deficits. The Journal of Economic Perspectives, Vol. 3, No. 2, pp. 37-54.

8. Cherif, R., Hasanov, F. (2018). Public debt dynamics: The effects of austerity, inflation, and growth shocks. Empirical Economics, Vol. 54, No. 3, pp. 1087-1105.

9. Chitiyo, K. T. (2000). Land violence and compensation: Re-conceptualising Zimbabwe's land and war veterans' debate. Center for Conflict Resolution: Harare. Available at http://ccrweb.ccr.uct.ac.za/two/9_1/zimbabwe.html [23 February 2021].

10.Dedu, V., Stoica, T. (2012). Central bank independence. Theoretical and Applied Economics, Vol. XIX, No. 8(573), pp. 97-102.

11.Elliot, G., Rothenberg, T. J., Stock, J. H. (1996). Efficient tests for an autoregressive unit root. Econometrica, Vol. 64, No. 4. pp. 813-836.

12.End, N., Tapsoba, S. J. A., Terrier, G., Duplay, R. (2015). Deflation and public finances: Evidence from the historical records, IMF Working paper, WP/15/176. Washington DC. Available at https://www.imf.org/external/pubs/ft/wp/2015/wp15176.pdf [19 February 2021].

13. Friedman, M. (1970). The counter revolution in monetary theory. Occasional paper no. 33. IEA. London.

14.Glynn, J., Perera, N., Verma, R. (2007). Unit root tests and structural breaks: A survey with applications. Journal of Quantitative Methods for Economics and Business Administration, Vol. 3, No. 1, pp. 63-79.

15.Government of Zimbabwe (GoZ). (2009a). Mid-term fiscal statement. Ministry of Finance and Economic Development. Harare. Government Printers.

16.Government of Zimbabwe (GoZ). (2009b). Short-term emergency recovery programme. Ministry of Finance and Economic Development. Harare. Government Printers.

17. Hanke S., Kwok, A. (2009). On the measurement of Zimbabwe's hyperinflation. Cato Journal, Vol. 29, No. 2, pp. 353-364.

18. Hilbers, P. (2005). Interaction of monetary and fiscal policies: Why central bankers worry about government budgets, Chapter 8. IMF papers. International Monetary Fund: Washington DC. Available at https://www.imf.org/external/np/leg/sem/2004/cdmfl/eng/hilber.pdf [16 February 2021].

19. Hilscher, J., Raviv, A., Reis, R. (2020). Inflating away the public debt? An empirical assessment. Available at https://personal.lse.ac.uk/reisr/papers/99HilscherRavivReisdebt.pdf [18 February 2021].

20.International Monetary Fund (IMF). (2009). Zimbabwe: IMF executive board concludes 2009 Article IV Consultation with Zimbabwe: Public information Notice No. 09/53. Washington DC. Available

at https://www.imf.org/en/News/Articles/2015/09/28/04/53/pn0953 [16 February 2021].

21.International Monetary Fund (IMF). (2014). Zimbabwe: 2014 Article IV Consultation - Staff report; Press release; and Statement by the executive director for Zimbabwe. IMF Country Report No. 14/202: Washington DC.

22.International Monetary Fund (IMF). (2016). Zimbabwe: 2016 Article IV Consultation-Staff report press release; and statement by the executive director for Zimbabwe. Washington DC. Available at https://www.imf.org/en/Publications/CR/Issues/2016/12/31/Zimbabwe- 
Staff-Report-for-the-2016-Article-IV-Consultation-and-the-Third-Review-of-the-Staff-43882 [16 February 2021].

23.International Monetary Fund (IMF). (2019a). Staff-Monitored Program - Press Release and Staff Report. IMF Country Report No. 19/144. Washington DC.

24.International Monetary Fund (IMF). (2019b). Inflation and public debt reversals in advanced economies. IMF Working paper WP/19/297. Washington DC.

25.International Monetary Fund (IMF). (2020). 2019 Article IV Consultation - Staff Report; Press Release; and Statement by the Executive Director for Zimbabwe. IMF Country Report No. 20/82. Washington DC.

26.Jones, T. (2011). Uncovering Zimbabwe's debt: The case for a democratic solution to the unjust debt burden. Jubilee Debt Campaign. London.

27.Kairiza, T. (2012). Unbundling Zimbabwe's journey to hyperinflation and official dollarization. GRIPS Policy Information Centre. Discussion paper 09-12. Tokyo.

28.Keynes, J. M. (1936). The General Theory of Employment Interest and Money. McMillan, London.

29.Krause, M. U., Moyen, S. (2016). Public debt and changing inflation targets. American Economic Journal: Macroeconomics, Vol. 8, No. 4, pp. 142-176.

30.Kwon, G., McFarlane, L., Robinson, W. (2009). Public debt, money supply, and inflation: A cross-country study. IMF Staff Papers, Palgrave Macmillan, Vol. 56, No. 3, pp. 476-515.

31.Laidler, D., Parkin, M. (1975). Inflation: A survey. The Economic Journal, Vol. 85, No. 340, pp. 741-809.

32.Lawal, A. I., Somoye, R. O., Babajide, A. A., Nwanji, T. I. (2018). The effect of fiscal and monetary policies interaction on stock market performance: Evidence from Nigeria. Future Business Journal, Vol. 4. No. 1, pp. 16-33.

33.Lopes da Veiga, J. A., Ferreira-Lopes, A., Sequeira, T. N. (2016). Public Debt, Economic Growth and Inflation in African Economies. South African Journal of Economics, Vol. 84, No. 2, pp. 294-322.

34.Madito, O., Odhiambo, N. M. (2018). The main determinants of inflation in South Africa: An empirical investigation. Organizations and Markets in Emerging Economies, Vol. 9, No. 2, pp. 212-232.

35. Makochekanwa, A. (2010). The impact of a budget deficit on inflation in Zimbabwe, MPRA Paper No. 24227. Available at https://mpra.ub.uni-muenchen.de/24227/ [16 February 2021].

36.Mankiw, N. G. (Ed.). (2012). The Monetary System, Money Growth and Inflation. Chapter 8. Available

https://www.econ.cmu.ac.th/econadmin/files/Chapter\%208\%20Monentary\%20System\%20 Handout\%20Student.pdf [21 February 2021].

37.Mas, R. D., Vonessen, B., Fehlker, C., Arnold, K. (2020). The case for central bank independence. European Central Bank. Occasional paper series. No 248 / October 2020.

38. Ministry of Finance and Economic Development (2021). Budget statement. (Various years). Ministry of Finance and Economic Development. Harare. Government Printers.

39. Mohanty, M. S. (2012). Fiscal policy, public debt and monetary policy in EMEs: An overview. Bank for International Settlements. BIS Papers No 67. Available at https://www.bis.org/publ/bppdf/bispap67.pdf [24 February 2021].

40.Mohr, P. (2008). On inflation. South African Journal of Economics, Vol. 76, No. 1, pp. 1-15.

41.Mupunga, N., Le Roux, P. (2014). Analysing the theoretical and empirical foundations of public debt dynamics in Zimbabwe. Economic Research Southern Africa, pp. 1-20.

42.Mupunga, N., Le Roux, P. (2015). Estimating the optimal growth-maximising public debt threshold for Zimbabwe. Southern African Business Review, Vol. 19, No. 3, pp. 102-128.

43. Narayan, P., Smyth, R. (2009). Multivariate granger-causality between electricity consumption, exports and GDP: Evidence from a panel of Middle Eastern countries. Energy Policy, Vol. 37, No. 1, pp. 229-236.

44.Newey, W., West, K. (1987). A simple, positive semi-definite, heteroscedasticity and autocorrelation consistent covariance matrix. Econometrica, Vol. 55, No. 3, pp. 703-708. 
45.Nguyen, V. B. (2015). The relationship between public debt and inflation in developing countries: Empirical evidence based on difference panel GMM. Asian Journal of Empirical Research, Vol. 5, No. 11, pp. 221-236.

46.Nyarota, S., Kavila, W., Mupunga, N., Ngundu, T. (2016). An empirical examination of negative inflation in Zimbabwe. Reserve Bank of Zimbabwe Working papers. Harare.

47.Odhiambo, N. M. (2021a). Foreign direct investment and economic growth in Kenya: An empirical investigation. International Journal of Public Administration, DOI: $10.1080 / 01900692.2021 .1872622$

48. Odhiambo, N. M. (2021b). Energy consumption and economic growth in Botswana: empirical evidence from a disaggregated data. International Review of Applied Economics, Vol. 35, No. 1. pp. 3-24.

49.Pesaran, M. H., Shin, Y. (1999). An autoregressive distributed lag modelling approach to cointegration analysis. In Econometrics and Economic Theory in the 20th Century, Chapter 11, pp. 1-31, Storm, S. (Ed.), The Ragnar Frisch Centennial Symposium, Cambridge University Press, London.

50.Pesaran, M. H., Shin, Y., Smith, R. (2001). Bound testing approaches to the analysis of level relationship. Journal of Applied Econometrics, Vol. 16, No. 3, pp. 174-189.

51.Phillips, P. C. B., Perron, P. (1988). Testing for a unit root in a time series regression. Biometrika, Vol. 75, No. 2, pp. 335-346.

52.Radovic, M., Radonjic, M., Djuraskovic, J. (2018). Central Bank Independence: The case of the central bank of Montenegro. Journal of Central Banking Theory and Practice, Vol. 7 , No. 3, pp. 25-40.

53.Rehbein, K. (2012). How it could work: The alternative to the traditional debt relief processes for Zimbabwe: An illustration. The European Network on Debt and Development. Available at https://www.eurodad.org/files/pdf/520a390787e0e.pdf. [04 June 2021].

54.Reinhart, C. M., Sbrancia, M. B. (2015). The liquidation of government debt. Economic Policy, Vol. 30, No. 82, pp. 291-333.

55.Romero, J. P. B., Marin, K. L. (2017). Inflation and public debt. Monetaria, Vol. V, No. 1, pp. 39-94.

56.Saatcioglu, C., Korap, L. (2008). Long-run relations between money, prices and output: The case of turkey. Zku Sosyal Bilimlmer Dergisi, Vol. 7, No. 4, pp. 33-54.

57.Saungweme, T., Odhiambo, N. M. (2018). Debt dynamics in Zimbabwe: Reforms, trends and challenges. The International Journal for Quality Research, Vol. 12, No. 1, pp. 95-110.

58.Saungweme, T., Odhiambo, N. M. (2020). The Impact of Domestic and Foreign Public Debt on Economic Growth: Empirical Evidence from Zimbabwe. Economia Internazionale, Vol. 73, No. 1, pp. 77-106.

59.Sims, C. A. (2014). Inflation, Inflation Fears, and Public Debt. Princeton University. Available at http://sims.princeton.edu/yftp/Lindau/LindauSlides.pdf [15 February 2021].

60.Sims, C. A. (2016). Fiscal policy, monetary policy and central bank independence. Available

https://www.kansascityfed.org/ /media/files/publicat/sympos/2016/econsymposium-simspaper.pdf? la=en (18 February 2021).

61.Uctum, M., Thurston, T., Unctum. R. (2006). Public debt, the unit root hypothesis and structural breaks: A multi-country analysis. Economica, Vol. 73, No. 289, pp. 129-156.

62. World Bank. (2020). World development indicators. World Bank: Washington DC. Available at https://databank.worldbank.org/data/databases.aspx. [20 February 2021].

63.Zangari, E., Caiumi, A. Hemmelgarn, T. (2017). Tax uncertainty: Economic evidence. Working paper no. 67. European Union. Available at https://ec.europa.eu/taxation_customs/sites/taxation/files/taxation_paper_67.pdf [18 February 2021].

64.Zivot, E., Andrews, D.W. (1992). Further evidence on the great crash, the oil-price shock, and the unit-root. Journal of Business and Economic Statistics, Vol. 10, No. 3, pp. 251-270. 


\section{About the authors}

Talknice Saungweme holds a PhD (Economics) from University of South Africa. His research has over the years been concentrated in public sector economics, international economics and macroeconomic policies. His career goal is to contribute positively to macroeconomic policy development, mostly in low-income countries and in emerging economies. He is currently an Economics lecturer at Great Zimbabwe University and a Research Chairperson at this university. He has researched widely on public debt, inflation and economic growth issues in several African countries. The author can be contacted talknice2009@gmail.com.

Nicholas M. Odhiambo is a Professor of Economics and holds a PhD (Economics) degree from Stellenbosch University (South Africa). His research has over the years focused on the dynamic linkages between the various macroeconomic policies in developing countries and their effect on economic growth and poverty reduction. He has a strong bias towards subSaharan African countries, which are currently ravaged by low levels of economic growth in per capita terms and high levels of poverty. He is currently a Professor and Chair of Macroeconomic Policy Analysis (MPA) research flagship programme in the Department of Economics, at the University of South Africa (UNISA). The author can be contacted odhianm@unisaac.za and nmbaya99@yahoo.com.

\section{APPENDIX}

\section{The Zivot-Andrews (1992) unit root test with an unknown break- point in the deterministic trend function}

The deterministic trend of the inflation series is influenced by a: (i) change in mean (Model A); (ii) change in slope (Model B); or by (iii) both changes (Model C).

\section{Model A: Change in mean}

$$
b_{t}=\mu_{1}+\theta_{1} D U_{t}(\pi)+\beta_{1} t+\phi_{1} b_{t-1}+\sum_{j=1}^{k} \delta_{1 j} \Delta b_{t-j}+e_{1 t}
$$

Model B: Change in slope

$$
b_{t}=\mu_{2}+\gamma_{1} D T_{t}(\pi)+\beta_{2} t+\phi_{2} b_{t-1}+\sum_{j=1}^{k} \delta_{2 j} \Delta b_{t-j}+e_{2 t}
$$

Model C: Change in mean and slope

$$
b_{t}=\mu_{3}+\theta_{2} D U_{t}(\pi)+\gamma_{2} D T_{t}(\pi)+\beta_{2} t+\phi_{3} b_{t-1}+\sum_{j=1}^{k} \delta_{3 j} \Delta b_{t-j}+e_{3 t}
$$

where $\pi=\mathrm{d} / \mathrm{T}$ is the unknown sample ratio to be estimated; $\mathrm{T}$ is the number of observations; $d$ is the unknown break point; the level dummy $\operatorname{DU}_{t}(\pi)=1$ if $t>$ $\mathrm{d}$ and 0 otherwise. The slope dummy $\mathrm{DT}_{\mathrm{t}}(\pi)=\mathrm{t}-\mathrm{d}$ if $\mathrm{t}>\mathrm{d}$ and 0 otherwise. The null hypothesis of a unit root is that $\phi_{\mathrm{i}}=1, \mathrm{i}=1,2,3$. The ADF statistics, $\mathrm{t}\left(\widehat{\phi}_{\mathrm{i}}\right)$ are computed for each value of $\pi$ and the $\inf \left[\mathrm{t}\left(\widehat{\phi}_{\mathrm{i}}\right)\right]$ statistics are used for testing the null hypothesis against the trend-stationary alternative. The null hypothesis is rejected if these statistics are less than their asymptotic critical values (e.g. Uctum et al., 2006; Zivot, Andrew, 1992). 